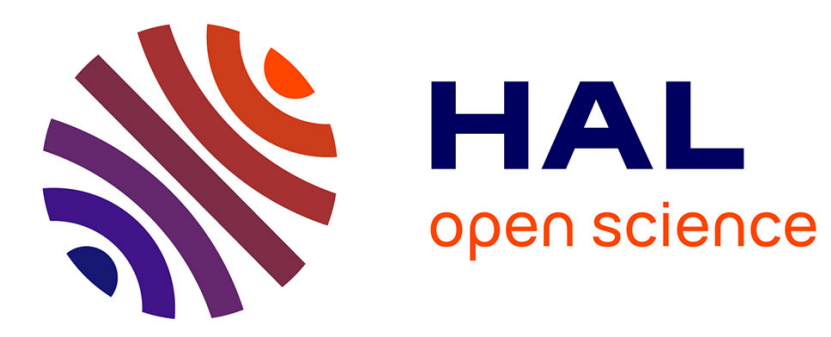

\title{
Performance Indicators for the Evaluation of Product-Service Systems Design: A Review
}

Dimitris Mourtzis, Sophia Fotia, Michael Doukas

\section{To cite this version:}

Dimitris Mourtzis, Sophia Fotia, Michael Doukas. Performance Indicators for the Evaluation of Product-Service Systems Design: A Review. IFIP International Conference on Advances in Production Management Systems (APMS), Sep 2015, Tokyo, Japan. pp.592-601, 10.1007/978-3-319-22759-7_68 . hal-01431149

\section{HAL Id: hal-01431149 \\ https://hal.inria.fr/hal-01431149}

Submitted on 10 Jan 2017

HAL is a multi-disciplinary open access archive for the deposit and dissemination of scientific research documents, whether they are published or not. The documents may come from teaching and research institutions in France or abroad, or from public or private research centers.
L'archive ouverte pluridisciplinaire HAL, est destinée au dépôt et à la diffusion de documents scientifiques de niveau recherche, publiés ou non, émanant des établissements d'enseignement et de recherche français ou étrangers, des laboratoires publics ou privés. 


\title{
Performance Indicators for the Evaluation of Product-Service Systems Design: A Review
}

\author{
Dimitris Mourtzis $^{1, *}$, Sophia Fotia ${ }^{1}$, Michael Doukas $^{1}$ \\ ${ }^{1}$ Laboratory for Manufacturing Systems \& Automation, Department of Mechanical Engineering \\ \& Aeronautics, University of Patras, 26500, Greece \\ \{mourtzis@lms.mech. upatras.gr\}
}

\begin{abstract}
Recently, industries have shifted their focus on the combined ecosystem of products-services. The innovative business strategy of PSS provides an integrated solution that gives the potential for sustainability gains for both company and customer. Similarly to other business aspects, the PSS efficiency design is evaluated through performance indicators, during the phase of concept evaluation, which is the last phase before launching a product-service. This phase plays a critical role for the success of a PSS. A successful evaluation prevents design modifications or redesign, significantly reduces the cost and lead time of PSS development. There is however, limited work on integrated evaluation approaches for PSS design models, and also a lack of a collective accounting of the most important key performance indicators (KPIs) devoted on PSS. The present work attempts to contribute in these directions, and proposes a conceptual framework for the effective evaluation of PSS design using important KPIs.
\end{abstract}

Keywords: Product Service System (PSS), Key Performance Indicators (KPIs)

\section{Introduction}

The intensive global competition and technological advances force the actors of a supply chain to optimize their activities in order to deliver high-value productsservices with low costs and diminished time-to-market. This optimization relies on waste elimination, improved process control, efficient manpower utilization, and employment of smart and flexible systems [1]. PSS is a value proposition strategy that offers products-services and is designed to be: competitive, satisfy customer needs, and have a lower environmental impact than traditional business models [2]. The importance of the shift towards selling functionality instead of products is illustrative by the fact that software and electronics add nearly $40 \%$ to the cost of a new car nowadays, while this figure is bound to increase [3]. Moreover, measuring the performance of a PSS offering is crucial for a firm, since it influences its competitiveness in the market, its cost-effectiveness, and finally, its overall business performance [2], [4,5]. Following the principle of "what cannot be measured cannot be improved" and

\footnotetext{
*Corresponding Author.

adfa, p. 1, 2011.

(C) Springer-Verlag Berlin Heidelberg 2011
} 
the plan-do-check-act methodology [6], continuous monitoring of the implemented processes is required during the entire lifecycle of the system. Thus, the use of KPIs is necessary. KPIs can provide insights about the performance of a company and can facilitate decision making. Moreover, KPIs can be employed to reduce non-adding value activities, which comprise approximately the $60 \%$ of a company's activities [7]. Due to the significant differences between products and services, the concept evaluation of PSS differs from ordinary evaluation problems. Product characteristics and service activities influence one another, creating difficulties in defining the weight factors of each evaluation criterion. However, there are few works concerning PSS performance indicators [8].

Except for limited research on integrated evaluation approaches for PSS models [9], there is a lack of studies that collect the main KPIs for measuring the efficiency of a PSS. The proposed work contributes with a collection and discussion of major PSS design models and existing KPIs that are appropriate for the PSS design activity.

\section{$2 \quad$ PSS design models}

The design models are simplified descriptions of the design process to assist the designer accomplishing the task. Although a great amount of literature work has been focused on PSS design models [10-32], there are surprisingly limited studies on integrated evaluation models for PSS [9], as well as collective accounting KPIs that could be used on PSS. In order for such a collection to be accomplished, the literature devoted to PSS design models and KPIs, is taken into account under a comparative review.

The review methodology that is followed to identify and collect KPIs for specific PSS designs is shown in Fig. 1. After examining the PSS design models, requirements for performance measurement are extracted, and finally, the KPIs that satisfy these requirements are classified. As Fig. 1 illustrates, the light gray area includes the major PSS design models, applicable and representative in the category that they belong to. The dark gray area consists of the requirements derived from these models. It is noted that some models belong to more than one category. The color coding is used to group KPIs under four general representative classes, namely KPIs for Business, Customers, Leanness, and Sustainability.

PSS is strongly related to sustainability and customer, thus, increasing sustainability and satisfying the customers should be the target of every PSS design model [2], [4,5]. Several models [10-13] have been developed with dominant aims these two aspects, thus, evaluation approaches measuring them through PSS are of great importance. Sustainability has three pillars: (i) Environment, (ii) Economy, and (ii) Society [14], while customer perspective mainly contains requirements associated to satisfaction and acceptability [15]. Indeed, Fig. 1 depicts that the most frequent requirements of PSS models are Customer and Sustainability.

One of the first approaches to model PSS design [16], aims to synchronize the development processes of the products and the services, incorporating the input from the customer in the process. Under the same concept, the Propensity Framework [17] 
attempts to enable a synergy between products and services, via the Front-End of Innovation (FEI) process, and using evaluation criteria based on customer's expectations and user experience.

According to many researchers [18-20], in order to achieve a competitive PSS, the integration of physical product and services should be considered in the early phase of design. At these models, the customer value is also identified in the first phase of design. Similarly, in the Shell model [21], which is proposed for PSS Engineering development, the customer is considered in the beginning of the design giving explicit feedback to the design procedure of the model.

Inspired by the similarity between service design and hardware design process, the fast-track design process is proposed in [22]. Importantly, the authors stress that the use of this methodology ensures that the customer becomes fully aware of the value of the total care product business solution. Moreover, they present many PSS oriented requirements for performance measurement, namely service reliability, maintenance, stability, uncertainty, average waiting times, and reliability (short- and long-time). Finally, they outline the importance of quantitative performance measurements in the functional product provision.

Similar requirements are extracted by IPS $^{2}$ models [20], [23,24], Service models [25, 26], ServiceCAD/CAD PSS [26-28], Life Cycle Simulation (LCS) [26],[29] design models, Knowledge-sharing network for PSS design [30], and web PSS [31] design models. In addition to the aforementioned requirements, the necessity of measuring the server's availability, risk, and knowledge-sharing aspects, has been also considered.

Moreover, lean product-service design approaches are another requirement for competitiveness. The lean approach focuses on eliminating non-value activities from processes by applying a robust set of performance change tools, and emphasizes on excellence in operations to deliver superior customer service. To grasp the lean approach in a service-company, senior managers must recognize that all organizationsmanufacturing and non-manufacturing-ultimately deliver value to a customer in the form of a product and/or service [32]. Indicators of how lean is the system [33] are significant to establish such a design. 


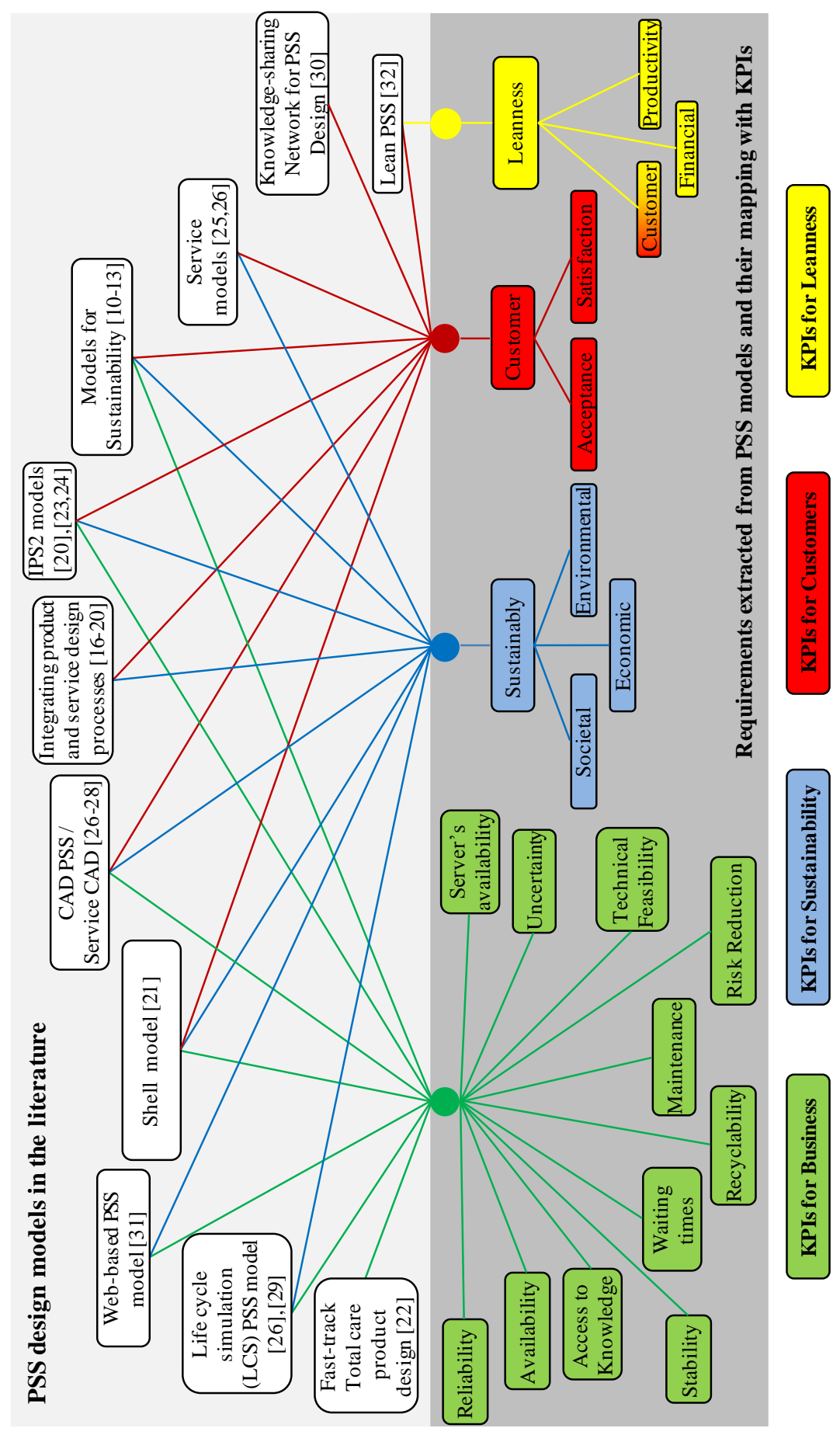

Fig. 1. PSS design models, evaluation requirements, and mapping of KPIs 


\section{$3 \quad$ KPIs for assessment of PSS design}

This section discusses the most appropriate KPIs for PSS assessment. The definition of KPIs depends on each problem's specific objectives, goals, and criteria [1]. Academic research has proposed a number of methodologies for developing and selecting KPIs according to the objectives of each company. The development of KPIs can follow the SMART principle i.e. being specific, measurable, attainable, realistic, and timely [34]. It is also crucial to notice that performance measurement systems should focus on what is important to measure and not simply what is easily measureable [35, 36]. According to these principles, an attempt to collect the appropriate KPIs for PSS design evaluation is carried out. KPIs are classified with respect to the direction of fulfillment requirements. These classes are the following: Customers (C), Business (B), Sustainability (S), and Leanness (L). Summarizing, Table 1 lists the KPIs that are associated to PSS design. It is commonly accepted that the realization of value in a PSS can only be achieved when customers are on focus and if services' evaluation is strongly connected to them [37]. Customer satisfaction and customer acceptance are among the most useful measures for several business strategies, and many researchers have developed measurement approaches and indicators for these purposes [38-45]. In this direction, the SERVQUAL scale [38] is introduced for assessing customer perception of service quality in service and retail companies. Additionally, another evaluation approach is proposed using importance-performance analysis, since the attributes of performance and importance are not independent variables, and the performance has a non-linear relationship with the overall satisfaction [44].

In the context of sustainability assessment of a PSS, most studies stress the 'environmental' aspect, probably since this aspect is measured relatively easily. There are limited methods that focus on measuring simultaneously all three sustainability components [45]. Environmental performance is usually connected with energy efficiency [46-49] and the level of material use in lease / reuse the PSS systems for waste prevention [50]. However, the consideration of social and economic dimensions are also important measures of sustainability [45]. In this direction, the Analytical Hierarchy Process is used in [51] to weight the importance of the indicators for each company under sustainability terms. The authors propose the use of sustainable product-service efficiency indicator, as to ratio of the product service value to its sustainability impact.

As shown in Fig. 1, the class of KPIs for Business is the most literature-stressed approach for the evaluation of PSS. The five phases of the PSS lifecycle, i.e. the planning, development, implementation, delivery and use, and closure are defined in [52]. Usually, the performance measure of these five phases falls under the customer-based measures. Particularly, the planning of the PSS is closely related to the customer as it includes the requirements, specifications, and the offer of a customised PSS. An indicator framework is the foundation of the measurement and monitoring of Industrial PSS (IPS ${ }^{2}$ ) in the use-oriented business model [34]. 
Table 1. KPIs for PSS design assessment (Customer:C, Buisiness:B, Sustainability:S, Lean:L)

\begin{tabular}{|c|c|c|c|c|c|}
\hline KPIs & Reference & Class & KPIs & Reference & Class \\
\hline Satisfaction & [37-44] & $\mathrm{C}$ & $\begin{array}{l}\text { Overall Equipment } \\
\text { Effectiveness }\end{array}$ & [34] & B \\
\hline Acceptability & {$[15],[39]$} & $\mathrm{C}$ & Technical availability & [34] & B \\
\hline Acceptance rate & {$[42,43]$} & $\mathrm{C}$ & Flexibility & [34] & B \\
\hline $\begin{array}{l}\text { Availability for pro- } \\
\text { duction plan }\end{array}$ & [34] & $\mathrm{C}$ & Stability & [34] & B \\
\hline $\begin{array}{l}\text { Number of identified } \\
\text { customer needs }\end{array}$ & [41] & $\mathrm{C}, \mathrm{L}$ & Machine Reliability & [34] & B \\
\hline $\begin{array}{l}\text { Consideration of } \\
\text { customer needs }\end{array}$ & [41] & $\mathrm{C}, \mathrm{L}$ & Service Reliability & [34] & B \\
\hline On-time delivery & {$[40],[42]$} & $\mathrm{C}$ & Service Assurance & [34] & B \\
\hline Rescheduling quota & {$[42,43]$} & $\mathrm{C}$ & Team Qualification & [34] & $\mathrm{B}, \mathrm{C}$ \\
\hline $\begin{array}{l}\text { Efficiency of need } \\
\text { identification }\end{array}$ & [41] & $\mathrm{C}, \mathrm{L}$ & Feeling quality & [34] & $\mathrm{B}, \mathrm{C}$ \\
\hline Customer Needs rate & [41] & $\mathrm{C}, \mathrm{L}$ & $\begin{array}{l}\text { Knowledge } \\
\text { Management }\end{array}$ & [54-57] & B \\
\hline $\begin{array}{l}\text { Requirement Incon- } \\
\text { sistency }\end{array}$ & [41] & $\mathrm{C}, \mathrm{L}$ & $\begin{array}{l}\text { PS Maintenance Effi- } \\
\text { ciency }\end{array}$ & {$[42],[52]$} & B \\
\hline $\begin{array}{l}\text { Efficiency of collabo- } \\
\text { ration }\end{array}$ & [41] & $\mathrm{C}, \mathrm{L}$ & Development cost & [34] & B \\
\hline Privacy & [41] & $\mathrm{C}, \mathrm{L}$ & Service delivery costs & [43] & B \\
\hline Product flexibility & [34] & $\mathrm{C}, \mathrm{B}$ & $\begin{array}{l}\text { Environmental quality } \\
\text { cost function }\end{array}$ & [49] & S, B \\
\hline Expansion flexibility & [34] & C, B & No. of bottlenecks & [40] & $\mathrm{L}$ \\
\hline Energy Efficiency & [46-51] & S & $\begin{array}{l}\text { Scheduling Inefficien- } \\
\text { cy }\end{array}$ & [40] & $\mathrm{L}$ \\
\hline $\begin{array}{l}\text { Sustainable product- } \\
\text { service efficiency }\end{array}$ & [51] & $S$ & $\begin{array}{l}\text { Defects detected in } \\
\text { development stages }\end{array}$ & [40] & $\mathrm{L}$ \\
\hline Lease/ Reuse & [50] & $S$ & $\begin{array}{l}\text { Requirement Incon- } \\
\text { sistency }\end{array}$ & [40] & $\mathrm{L}$ \\
\hline
\end{tabular}

While developing the indicator framework, the PSS performance, PSS lifecycle cost, and influencing factors have to be identified as major aspects for the provider. In order to evaluate better the IPS ${ }^{2}$ delivery, a classification of performance indicators under the areas of delivery planning and delivery performance has been carried out [42]. The performance dimensions identified are: resource planning, management of the network partners, and IT system efficiency. The concept has been enhanced by introducing feedback loops in an IPS ${ }^{2}$ control model.

Moreover, knowledge has a high importance for PSS providers and its availability is a challenge. The provider needs an adequate knowledge about the end-user's process as well as a concrete knowledge about the product. To satisfy these requirements, an approach for evaluating the knowledge within a company and to specify the re- 
quired knowledge for providing a specific PSS is proposed in [54]. Furthermore, a conceptual model for assessing the readiness of collaborative networked organizations for PSS delivery is proposed in [55]. Finally, the terms risk and uncertainty have often been used interchangeably in industry [56]. A conceptual representation of risk and uncertainty is provided in [57]. The study proposes risk representation in relation to knowledge indeterminate and probabilistic or deterministic outcome.

\section{Conclusions}

This research work presents a collection of PSS design models and identifies the role and importance of KPIs in the PSS design. Secondly, it provides a collection of existing KPIs that are appropriate for PSS design, classifying them into customer-, business-, sustainability-, and leanness-based measures. This work could be a guideline for supporting the selection of appropriate KPIs for the evaluation of PSS. Further to that, taking into account the reviewed PSS design models [10-32], and their systematic reviews [5, 9], a conceptual framework for effective PSS design using KPIs is proposed (Fig. 2). According to this framework, the design procedure contains two main stages: (i) PSS design process, and (ii) PSS design expectations.

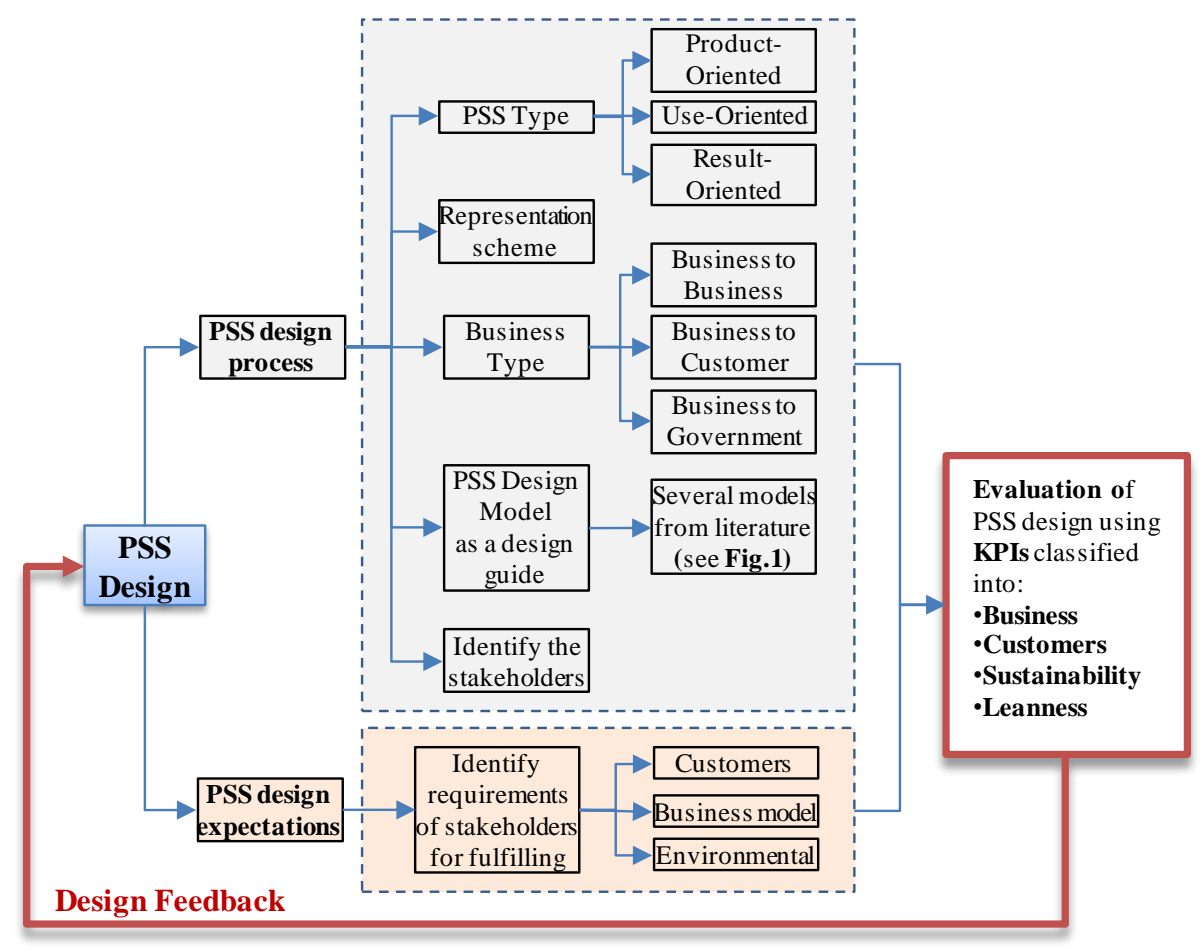

Fig. 2. The conceptual framework proposed for effective PSS design 
The first stage contains the specifications of the PSS type (product-, use-, and result- oriented [5]) according the product/service to be developed, also contains the Business type (Business to Business, Business to Customer, Business to Government), as well as the identification of stakeholders involved in the PSS. Furthermore, for an effective design procedure, a comprehensive PSS representation schema should be included [9].

The second stage focuses on what requirements the stakeholders have, and which of these have to be considered and fulfilled. This stage sets the basis of the evaluation strategy that has to be followed. For an effective PSS model, the fulfilling of the requirements of: Customers, Business model (e.g. Leanness, Sustainably, financial aspects), and Environment (e.g. energy consumption, $\mathrm{CO}_{2}$ emissions), has to be the main care. For this reason, the implementation of a comprehensive evaluation of the developed PSS model is needed, throughout their life-cycle, using appropriate KPIs. This KPIs give feedback to the designer for improving the PSS design.

Future work involves a systematic classification of evaluation approaches for PSS design and the formulation of KPIs in mathematical expressions together with mechanisms for their measurement.

Acknowledgements. This work has been partially supported by the H2020 EC funded project "Cloud Manufacturing and Social Software-based Context Sensitive Product-Service Engineering Environment for Globally Distributed Enterprise DIVERSITY" (GA No: 636692).

\section{References}

1. Chryssolouris, G., 2006. Manufacturing Systems: Theory and Practice. 2nd New York: Springer-Verlag

2. Mont, O.: Clarifying the concept of product-service system. The Journal of Cleaner Production. Volume 10. (2002) 237-245

3. Robert N. Charette, This Car Runs on Code, IEEE Spectrum 2009: http://spectrum.ieee.org/transportation/systems/this-car-runs-on-code

4. Goedkoop, M., van Halen, C.J.G., te Riele, H.R.M., Rommes, P.J.M.: Product Services Systems, Ecological and Economic Basics. VROM, (1999) The Hague

5. Baines, T., Lightfoot, H. W., Evans, S., Neely, A., Greenough, R., Peppard, J., Roy, R., Shehab, E., Braganza, A., Tiwari, A.: State-of-the-art in product-service systems, Proceedings of the Institution of Mechanical Engineers, Part B: Journal of Engineering Manufacture. Volume 221, no. 10. (2007) 1543-1552.

6. Gries, B., Restrepo, J.: KPI measurement in engineering design-A case study. International conference on engineering design, ICED11, Volume 1. (2011) 531-537

7. Dombrowski, U., Schmidtchen, K., Ebentreich, D.: Ballanced Key Performance Indicators in Product Development. International Journal of Materials, Mechanics and Manufacturing. Volume 1, no. 1. (2013) 27-31

8. de Castro Rodrigues, KF, Nappi, V., Rozenfeld, H., A proposal to support the value proposition in Product Oriented Service, business model of Product Service Systems, Procedia CIRP 16 ( 2014 ) $211-216$

9. Vasantha, G. V. A., Roy, R., Lelah, A., Brissaud, D.: A review of product-service systems design methodologies, Journal of Engineering Design. Volume 23, no. 9. (2012) 635-659 
10. Lelah, A., Mathieux, F., Brissaud, D., Vincent L.: Collaborative network with SMEs providing a backbone for urban PSS: a model and initial sustainability analysis, Production Planning \& Control: The Management of Operations, Volume 23, no 4. (2012) 299-314

11. Xing, K., Ness, D., Lin, F.: A service innovation model for synergistic community transformation: integrated application of systems theory and product-service systems, Journal of Cleaner Production, Volume 43. (2013) 93-102

12. Joore, P., Brezet, H.: A Multilevel Design Model: the mutual relationship between product-service system development and societal change processes, Journal of Cleaner Production (2014) , http://dx.doi.org/10.1016/j.jclepro.2014.06.043

13. Müller, P., Kebir, N., Stark, R., Blessing, L.: PSS layer method - application to microenergy systems, introduction to product/service-system design. Berlin: Springer, Part I, 3-30

14. Maxwell, D., van der Vorst, R.: Developing sustainable products and services. Journal of Cleaner Production. Volume 11. (2003) 883-895

15. Lee, Geum, Y., Lee, S., Park, Y.: Evaluating new concepts of PSS based on the customer value: Application of ANP and niche theory. Expert systems with Applications. Volume 42. (2015) 4556-4566

16. Aurich J.C., Fuchs, C., Wagenknecht, C.: Life cycle oriented design of technical ProductService Systems, Journal of Cleaner Production. Volume 14. (2006) 1480-1494

17. Dewit, I.: Towards a propensity framework for Product-service transitions, Proceedings of the 10th International conference on Tools and Methods of Competitive Engineering, TMCE'14, Budapest, Hungary, 2014

18. Y. Shimomura, T. Hara, T. Arai, A Unified representation scheme for effective PSS development, CIRP Annals - Manufacturing Technology. Volume 58. (2009) 379-382

19. Maussang, N., Zwolinski, P., Brissaud, D.: Product-service system design methodology: from the PSS architecture design to the products specifications, Journal of Engineering Design. Volume 20, no. 4. (2009) 349-366

20. Welp, E.G., Meier, H., Sadek, T., Sadek, K.: Modelling approach for the integrated development of industrial product-service systems. The 41 st CIRP conference on manufacturing systems, Tokyo, Japan, 2008

21. Weber, C., Steinbach, M., Botta, C., Deube, T.: Modelling of product-service systems (PSS) based on the PDD approach, in: the 8th International Design Conference, Dubrovnik, Dubrovnik, Croatia, 2004

22. Alonso-Rasgado, T., Thompson, G., Elfström, B.-O.: The design of functional (total care) products, Journal of Engineering Design, Volume 15, no. 6. (2004) 515-540.

23. Müller, P., Stark, R., A Generic PSS Development Process Model Based On Theory And An Empirical Study,in: International Design Conference, Dubrovnik, Croatia, 2010.

24. Sadek, , T.: Ein modellorientierter Ansatz zur Konzeptentwicklung industrieller ProduktService Systeme, Doctoral thesis, Ruhr-University Bochum, Institute: Product and Service Engineering, 2009

25. Rapaccini, M., Saccani, N., Pezzotta, G., Burger, T., Ganz W.: Service development in product-service systems: a maturity model, The Service Industries Journal, Volume 33, no. 3-4. (2013) 300-319

26. Komoto, H., Tomiyama, T.: Integration of a service CAD and a life cycle simulator, CIRP Annals - Manufacturing Technology. Volume 57. (2008) 9-12

27. Sakao, T., Shimomura, Y., Sundin E., Comstock, M.: Modeling design objects in CAD system for Service/Product Engineering, Computer-Aided Design. Volume 41. (2009) 197-213

28. McKay, A., Kundu, S.: A representation scheme for digital product service system definitions, Advanced Engineering Informatics. Volume 28. (2014) 479-498 
29. Garetti, M., Rosa, P., Terzi, S.,: Life Cycle Simulation for the design of Product-Service Systems, Computers in Industry. Volume 63. (2012) 361-369

30. Chirumalla, K., Bertoni, A., Ericson, A., Isaksson, O.: Knowledge-Sharing Network for Product-Service System Development: Is it atypical? The Philosopher's Stone for Sustainability. Berlin: Springer (2013) 109-114

31. Zhu, H., Gao, J., Li, D., Tang, D.: A Web-based Product Service System for aerospace maintenance, repair and overhaul services, Computers in Industry Volume 63. (2012) 338348

32. Resta, B., Powell, D., Gaiardelli, P., Dotti, S.: Towards a framework for lean operations in product-oriented product service systems. CIRP Journal of Manufacturing Science and Technology (2015), http://dx.doi.org/10.1016/j.cirpj.2015.01.008

33. Bhasin, S.: Lean and performance measurement, Journal of Manufacturing Technology Management. Volume 19, Iss. 5. (2008) 670 - 684

34. Abramovici, M., Jin, F., Dang, H. B.: An Indicator Framework for Monitoring IPS2 in the Use Phase, in: Product-Service Integration for Sustainable Solutions (2013) 311-322

35. Cedergren, S., Wall, A., Nostrom, C.: Evaluation of performance in a product development context. Business Horizons, Volume 53 (2010) 359-369

36. Driva, H., Pawar, K. S., Menon, U.: Measuring product development performance in manufacturing organosations. International Journal of Production Economics, Volume 63. (2000) 147-159

37. Kimita, K., Shimomura, Y., Arai, T.: Evaluation of customer satisfaction for PSS design, Journal of Manufacturing Technology Management. Volume 20, no. 5. ( 2009) 654-673

38. Parasuraman, A., Zeithaml, V. A., Berry, L. L.: SERVQUAL: A Multiple-Item Scale for Measuring Consumer Perceptions of Service Quality, Journal of Retailing. Volume 64. (1988) $12-40$

39. Griffin, A, Page, A., PDMA Success Measurement Project: Recommended Measures for Product Development Success and Failure, Journal of Product Innovation Management. Volume 13. (1996) 478-49

40. Mohammadi A.: Lean Product Development-Performance Measurement System, Master's Thesis, University of Gothenburg, School of Business, Economics and Law, 2010

41. Taisch M., Corti D., Terzi S.: Towards a Performance Measurement System for LeanOriented Global Product Development, Springer-Verlag Berlin Heidelberg, 2011

42. Morlock, F., Dorka, T., Meier, H.: Concept for a Performance Measurement Method for the Organization of the IPSS Delivery. Product Services Systems and Value Creation. Proceedings of the 6th CIRP Conference on Industrial Product-Service Systems, Procedia CIRP , 16, (2014) 56-61

43. Meier, H., Lagemann, H., Morlock, F., Rathmann, C.: Key Performance Indicators for assessing the planning and delivery of industrial services: in 2nd International Through-life Engineering Services Conference. Volume 11. (2013) 99-104

44. Geng, X., Chu X.: A new importance-performance analysis approach for customer satisfaction, Expert Systems with Applications. Volume 39. (2012) 1492-1502

45. Lee, S., Geum Y., Lee H., Park Y.: Dynamic and multidimensional measurement of product-service system (PSS) sustainability: a triple bottom line (TBL)-based system dynamics approach, Journal of Cleaner Production, Volume 32. (2012) 173-182

46. Olsthoorn, X., Tyteca, D., Wehrmeyer W.: Environmental indicators for business: a review of the literature and standardisation methods, Journal of Cleaner Production. Volume 9. (2001) 453-463 
47. May, G., Taisch, M., Geoghegan, K., Beccaris, M.: Improving Energy Efficiency in Manufacturing via KPI Intelligence Based on Plant Integration. In: 10th Global Conference on Sustainable Manufacturing, Istanbul, Turkey , 2012

48. Payman, A., Searcy C.: An analysis of metrics used to measure performance in green and sustainable supply chains, Journal of Cleaner Production.Volume 86. (2015) 360-377

49. El Saadany A. M. A., Jaber M. Y., Bonney M.: Environmental performance measures for supply chains, Management Research Review. Volume 34.(2011)1202 - 1221

50. T. Tasaki, S. Hashimoto, Y. Moriguchi: A quantitative method to evaluate the level of material use in lease/reuse systems of electrical and electronic equipment, Journal of Cleaner Production. Volume 14. (2006) 1519-1528

51. Chou, C. J., Chen, C. W., Conley, C.: An approach to assessing sustainable productservice systems, Journal of Cleaner Production. Volume 86. (2013) 277-284

52. Rese, M., Meier, H., Gesing, J., Boblau, M.: An Ontology of Business Models for Industrial Product-Service Systems, in: Y. Shinomura \& K. Kimita, eds. The philosopher's stone for sustainability: Proceedings of the 4th CIRP International Conference on Industrial Product-Service Systems. New York: Springer, (2012) 191-196

53. Lagemann, H., Meier, H.: Robust capacity planning for the delivery of Industrial ProductService Systems, Procedia CIRP. Volume 19. (2014) 99-104

54. Schenkl, S. A., Schmidt, D. M., Schockenhoff, D., Maurer, M.: Knowledge Evaluation for PSS Providers, Procedia CIRP 16 ( 2014 ) 86 - 91

55. Durugbo, C., Riedel, J.C.K.H., Readiness assessment of collaborative networked organisations for integrated product and service delivery, International Journal of Production Research. Volume 51, no 2. (2013) 598-613

56. Meier H., Roy R., Seliger G.: Industrial Product-Service Systems-IPS2 CIRP Annals Manufacturing Technology. Volume 59. (2010) 607-627

57. Erkoyuncu, J.A., Roy, R., Shehab, E., Wardle, P.: Uncertainty Challenges in Service Cost Estimation for Product-Service Systems in the Aerospace and Defence Industries. CIRP IPS2 Conference, Cranfield University, UK, (2009) 200-207 